Selection of Power Plants and Equipment for Stone Quarries in Iowa.

BI

G. W. BISSELL 


\section{SELECTION OF POWER PLANTS AND EQUIPMENT FOR STONE QUARRIES IN IOWA.}

i. W. BISSFLL.

\section{CONTENTS.}

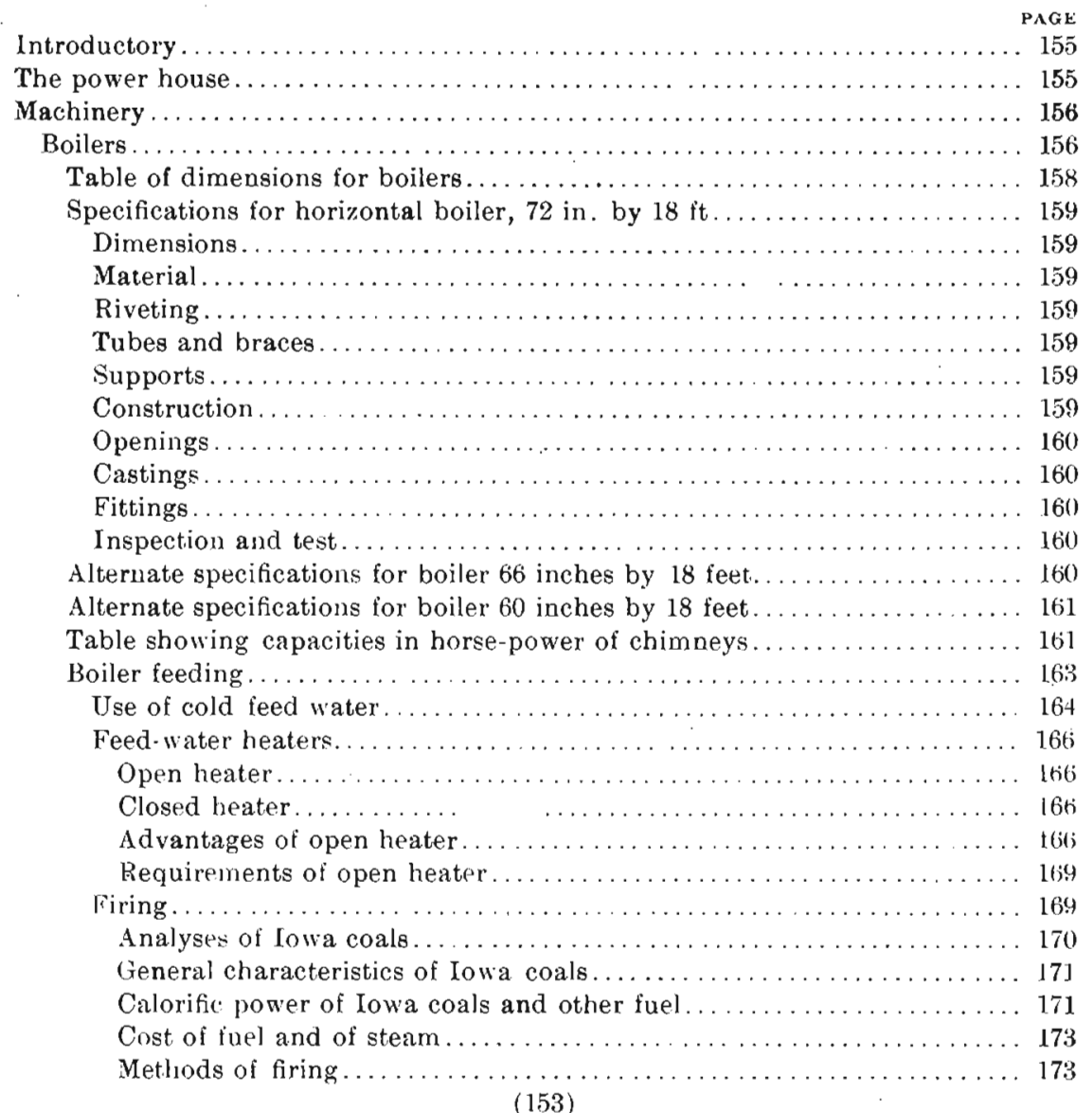


Engines. . . . . . . . . . . . . .

Proportions to be observed in selection. . . . . . . . . . . . . .

Effective power calculated . . . . . . . . . . . . . . . . . . . 15

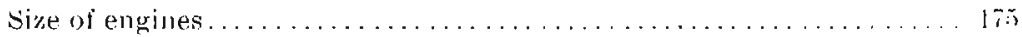

Hinor itens . . . . . . . . . . . . . . . . . . . . . . . . . . . . . . .

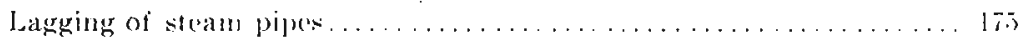

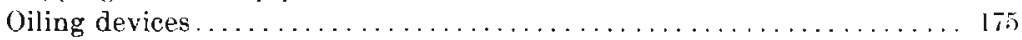

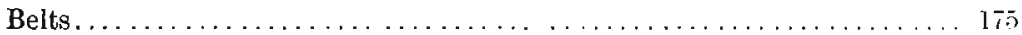

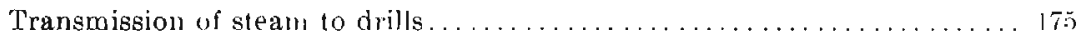

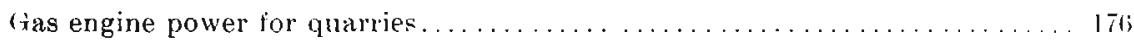

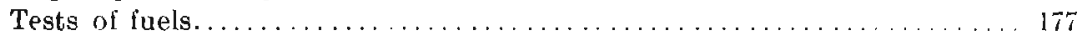

Tests of producer gas engine........................ 


\section{CHAPTER III.}

\section{*SELECTION OF POWER PLAN' AND FQUIPMENT FOR STONI: QUARRIES IN IOWA.}

It is the purpose of this report to discuss the principles governing the selection and installation of the engine and boiler plants which fornish the power required for quarrying and crushing stone, as prarticed generally in Towa quarries.

The writer las assmmed that in the selection of the power producing apratuatus the following reruirements exist: All machinery must be (1) simple in desigu, (2) strong in construction, (3) reliable in action, (4) reasonable in first cost, and (5) readily handlel by men of ordinary intelligence and some mechanical aptitude.

Economy of operation should also reccive some attention but since the operation of the plant is limited to the open season, economy is not of as much importance as the other requirements first named.

\section{The Power House.}

'The building in which the engines and boilers and accessories are placed need not be elaborate or expensive, but should be so constructed as to protect the machinery and its attendants from the weather while the plant is in nse, shonld protect the machinery from meddling yeusols and the weather while the plant is not in use and should be so located, and the machinery so arranged therein, that the capacity of the plant can be increased by adding to the existing building. Plenty of light and controllable ventilation are very desirable in the power house. If the quarry is large and likely to be worked for several seasons, it will pay to put up a substantial power house. The use of stone, as

* See also Iowa (ieological survey. vol. xir, p. s4 
masonry ol concrete, naturally suggests itself. and a good roof, doors and windows to he shrttered and harred during the winter should be included.

\section{Machinery.}

This consists usually of engives, hoilers and stacks, and feedpumps or injectors. For most locklities feed water purifiers should be added to the list. If crushing is not a part of the business, the boiler, which furuishes stean to the drill, is the principal item of ecjuipment. Undoulsted! luture practice will develop the use of the gas or gasoline engine for driving the crusher and air-compressol for drilling.

$$
\text { BOILFRS. }
$$

The most satisfactory all around boiler is the well known horizontal return tubular boiler shown without the brick work and eastings in Fig. 1, and wate XXVI. Fig. 1 represents a hoiler adapted to smspension, to whin reference $i$ made below. For Towa conl as firel the boiles should have relitively long tubes.

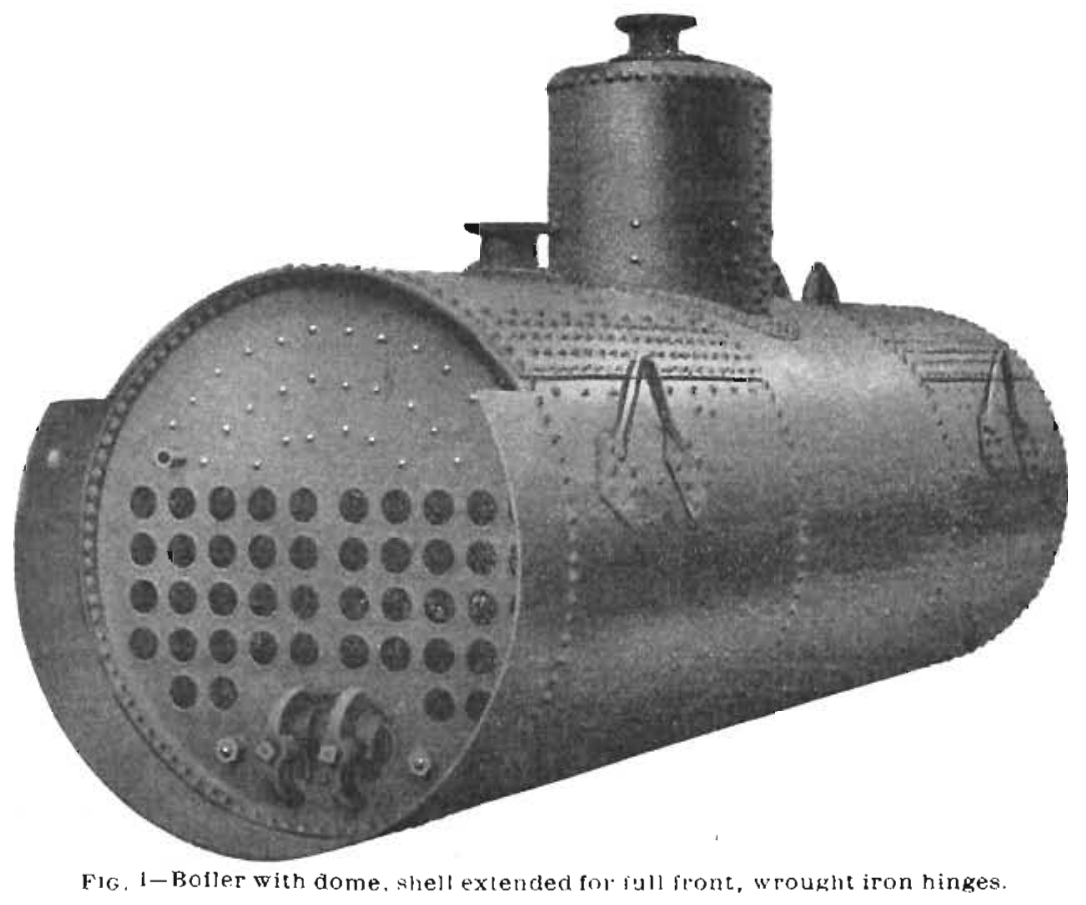




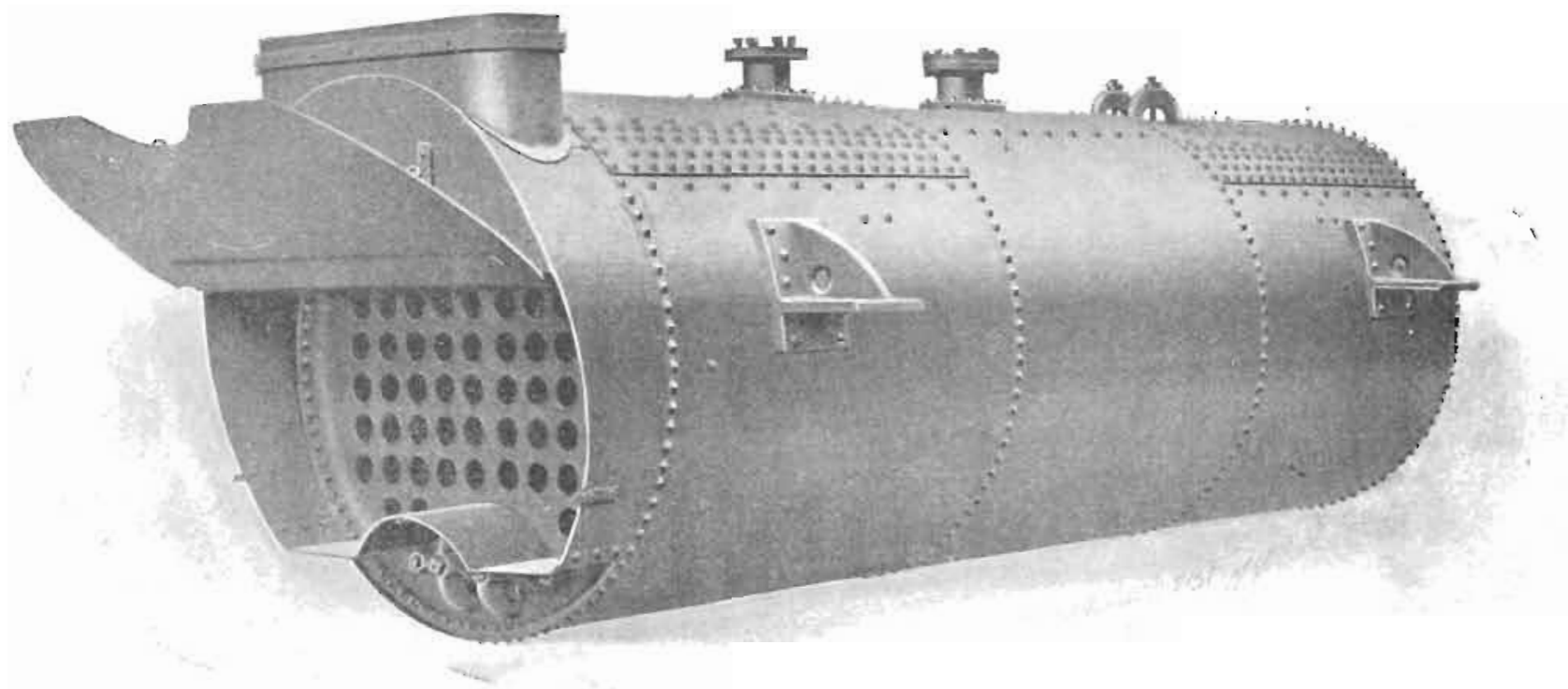

PLAT: XXVI-Domeless boiler with nozzles, shell extended and fitied with flue door and up-take for half arch iront, manhole exposed. cast iron lugs. Can be suspended. 
should be set high above the grates, should have liberal grate surface and be connected to a stack of ample capacity.

Tubes four inches in diameter should be eighteen feet long and three and one-half inch tubes should be sixteen feet long. Tubes smaller than four inches are not advisable for natural draft with Iowa coals, on account of the excessive soot accumulation in smaller tubes.

The grate surface should be liberal so as to permit the use of slack or the carrying of a heavy enough fire of any grade of Iowa coal to compel a thorough mixture of the air and combustible gases of the fuel.

Twelve square feet of water heating surface per boiler horse power, and one square foot of grate surface to each forty square feet of heating surface will be found satisfactory. Rocking and dumping grates are very desirable.

Automatic stokers are not practicable in plants for quarries in Iowa. Most boiler shells are too near the fire for the economical use of Iowa coal. A seventy-two-inch boiler should be not less than thirty-six inches above the grate. The following table contains approved dimensions for boilers of this type for shells from forty-eight inches to seventy-two inches in diameter, and from sixteen feet to eighteen feet in length, with four-inch tubes:

TABLE GIVING DTMENSIONS FOR BOILERS.

\begin{tabular}{|c|c|c|c|c|c|}
\hline 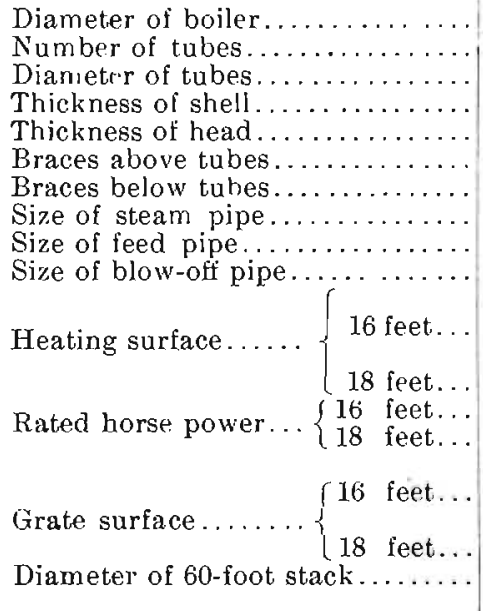 & $\begin{array}{c}48 \text { in. } \\
24 \\
4 \mathrm{in} . \\
\frac{5}{16} \cdot \mathrm{n} . \\
\frac{7}{10} \mathrm{in} . \\
12 \\
4 \\
3 \frac{1}{2} \mathrm{in} . \\
1 \mathrm{i} . \mathrm{in} . \\
2 \mathrm{in} . \\
\text { sq. feet } \\
520 \\
\text { sq. feet } \\
585 \\
43.3 \\
48.7 \\
\text { sq. feet } \\
14 \\
\text { sq. feet } \\
15.8 \\
24 \text { in. }\end{array}$ & $\begin{array}{c}54 \text { in. } \\
36 \\
4 \mathrm{in} . \\
\frac{5}{10} \mathrm{in} . \\
\frac{1}{2} \mathrm{in} . \\
20 \\
4 \\
4 \mathrm{in} . \\
1 \frac{1}{4} \mathrm{in} . \\
2 \mathrm{in} . \\
\text { sq. feet } \\
715 \\
\text { sq. feet } \\
805 \\
59.5 \\
67 \\
\text { sq. feet } \\
18 \\
\text { sq. feet } \\
22 \\
27 \text { in. }\end{array}$ & 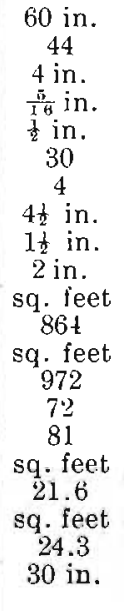 & $\begin{array}{c}66 \mathrm{in} . \\
54 \\
4 \mathrm{in} . \\
\frac{3}{8} \mathrm{in} . \\
\frac{9}{2} \mathrm{in} . \\
30 \\
4 \\
5 \mathrm{in.} \\
1 \frac{1}{2} \mathrm{in.} \\
2 \frac{1}{2} \text { in. } \\
\text { sq. feet } \\
1042 \\
\text { sq. feet } \\
1270 \\
87 \\
90 \\
\text { sq. feet } \\
30 \\
\text { sq. feet } \\
33 \\
33 \text { in. }\end{array}$ & $\begin{array}{c}72 \text { in. } \\
68 \\
4 \text { in. } \\
8 \text { in. } \\
\frac{9}{15} \text { in. } \\
40 \\
8 \\
6 \text { in. } \\
1 \text { in. } \\
2 \frac{1}{2} \text { in. } \\
\text { sq. leet } \\
1325 \\
\text { sq. feet } \\
1490 \\
110 \\
124 \\
\text { sq. feet } \\
33 \\
\text { sq. feet } \\
39.6 \\
36 \text { in. }\end{array}$ \\
\hline
\end{tabular}


Herewith is a standard "Specification" for boilers of the same type, based upon the practice recommended by the Hartford Steam Boiler Inspection and Insurance Company.

SPECIFICATYONS FOR HORIZONTAL RETURN TUBULAR BOILER, 72 INCHES BY 18 FEET.

Wurking Pressure, 125 Pot NIS.

Type.-Horizontal return tubular.

Dimensions.-Seventy-two inches in diameter, eighteen feet long from outside to outside of heads, with smoke extensions eighteen inches long continuous with shell. Thickness of shell, three-eighths inch, of head, one-half inch.

Material.-Best open hearth flange steel, having a tensile strength of not less than 57,000 nor more than 62,000 pounds, and deductility corresponding to 56 per cent reduction of area and 25 per cent of longation. All plates in finished boiler to show stamp with name of maker, quality and tensile strength.

Riveting.-Triple riveted butt-joints for longitudinal seams and single riveted lap joints for girth seams.

Tubes and Braces.-Sixty-eight tubes, four (4) inches in diameter, eighteen feet long, best lap welded or seamless drawn, carefully and properly expanded with Dudgeon expander and beaded at each end. Braces: Forty braces above tubes and four below tubes, the former crow foot form, flat or round, of not less than one square inch in area at smallest section, the latter $11 / 4$ inches in diameter, with up-set ends for $1 \frac{1}{2}$ inch tliread at front and crow-foot connections at back, with turned bolt 1 1-16 inch diameter. No brace less than 3 feet 6 inches long.

Details of tube sheet lay-out to be according to practice recommended by the Hartford Steam Boiler Inspection and Insurance Company.

Supports. - Two lugs on each side. Front lugs to rest on cast iron plates, others on rollers and plates to permit of expansion. All plates 12 by 12 by 11/2 inches. Rollers 1 inch diameter, 9 inches long, three at each plate. Or two suspension loops on each side, of $1 \frac{1}{2}$ inch round iron securely riveted to shell. Columns and double channels for overhead suspension, with equalizing I-beam at back end. See plate XXVII.

Construction.-No dome. Shell in three rings, each ring formed from a single sheet, horizontal seams above the fire 
and to break joints. Heads machine flanged, rivet holes drilled or punched and reamed, tube holes drilled or bored.

Openings.-Two man-holes, 11 by 15 inches in top of shell, 10 by 15 inches in front head, under tubes. One and one-half inch feed-water pipe, internal from front head over tubes. Blow-off flange 21/2 inches. Steam nozzle 5 inches, near back end, safety valve nozzle 4 inches, near front end. Both nozzles flanged and fitted with companion flanges for screved pipes of same size as nozzles.

Castings.-Fronts. Ornamental three-quarter arch for overhanging extension. Fronts designed to allow not less than 42 inches between grate and boiler shell and to have fire-door frames for 8-inch wall. Tight fitting fire, ash-pit and smoke extension doors, saddle for breaching connection with balanced butterfly damper. Eight wall binders, binder rods, anchor rods for front, soot door and skeleton frames for fire brick arch at back. Uptake 14 by 60 inches. Rocking dumping grates of approved design to work from front of boiler.

Fittings.-Eight-inch brass steam gauge, combination water column, 4 -inch pop safety valve, $11 / 2$-inch check and stop valves and $21 / 2$-inch asbestos blow-off cock.

Inspection and Test.-Before shipment test with cold water at 175 pounds per square inch and furnish certificate of inspection from the Hartford Steam Boiler Inspection and Insurance Company, and insurance policy in the same company for one year.

ALTERNATE SPECIFICATIONS FOR BOILER 66 INCHES BX 18 FEET,

Complying with specifications for the 72-inch boiler, except as follows :

Diameter, 66 inches. Length, outside to outside, 18 feet.

Thickness of shell, $3 / 8$-inch. Riveting, double riveted lap for longitudinal seams.

Fifty-four tubes, 4 inches by 18 feet.

Braces above tubes, 34 .

Braces below tubes, 4 .

Uptake, 12 by 54 inches.

Steam pipe, 41/2-inch. Safety valve, 31/2-inch.

Blow-off, 2-inch.

Feed pipe, 11/2-inch. 
ALTLRNATE SPECIFICATIONS FOR BOILER 60 INCHES BY 18 FEET.

Complying with the specifications for the 72-inch boiler, except as follows:

Diameter, 60 inches. Length, outside to outside, 18 feet.

Thickness of shell, 5-16 inch. Riveting, double riveted lap for longitudinal seams.

Forty-four tubes, 4 inches by 18 feet.

Braces above tubes, 30 .

Braces below tubes, 4.

Uptake, 12 by 42 inches.

Steam pipe, 4-inch. Safety valve, 31/2-inch.

Blow-off, 2-inch.

Feed pipe, 11/4-inch.

Complete specifications and setting plans for any size of horizontal return tubular boiler can be had by applying to the Hartford Steam Boiler Inspection and Insurance Company. In the judgment of the writer, they should be modified along the lines suggested in the above specifications.

The capacity of the stack depends upon its cross-sectional area, its height, the temperature inside and outside and general atmospheric conditions.

The table given below, adapted from a more complete table in Snow's "Steam Boiler Practice," p. 236, gives the capacities in horse power of chimneys or stacks of various heights and diameters for ordinary conditions as to temperature of the hot gases and for average atmospheric conditions.

TABLE SHOWING CAPACITIES IN HORSE-POWER OF CHIMNEYS.

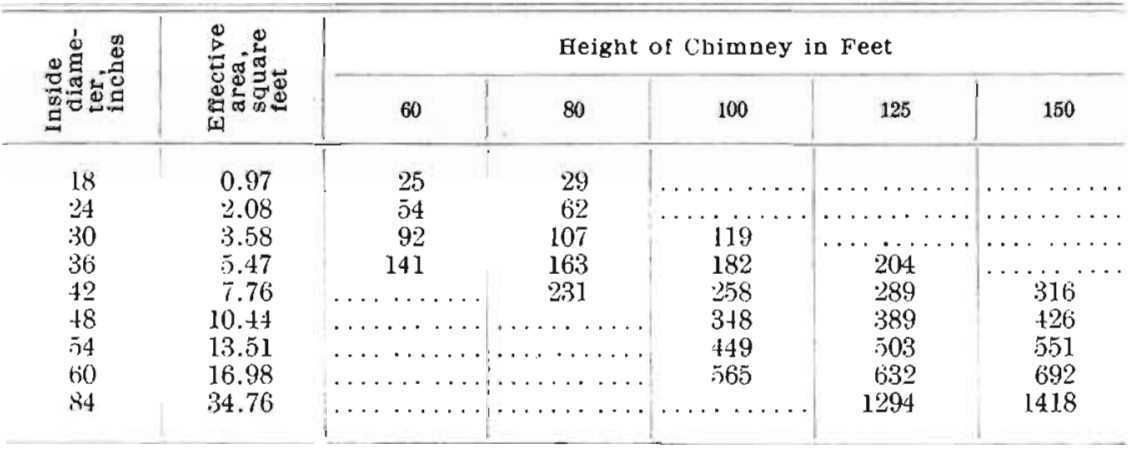




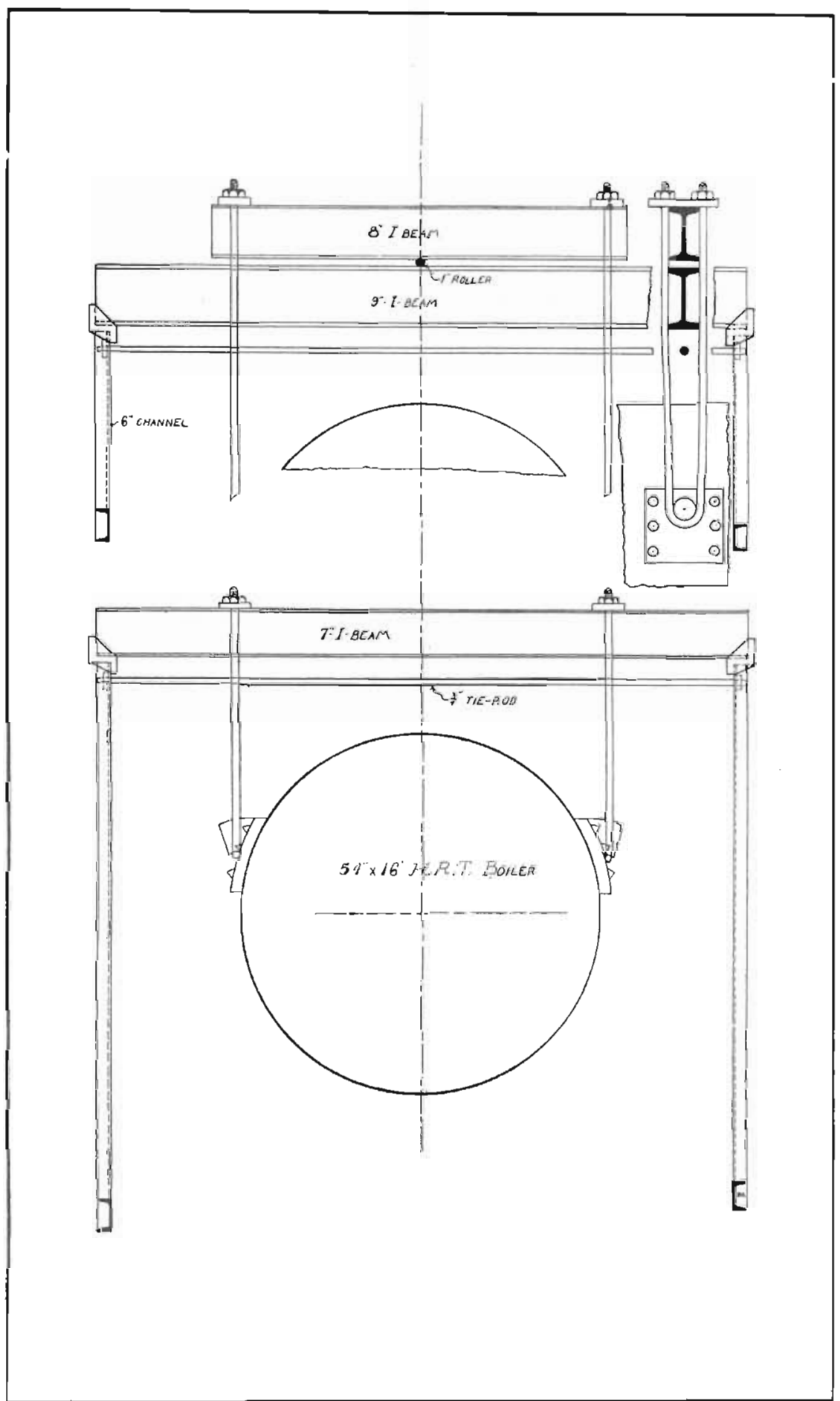

PLite XXVII-Mrthod of hanging a shell boiler. 
SETTING FOR ONE 72 INCH

Horizontal TUbuhar BOHLE.
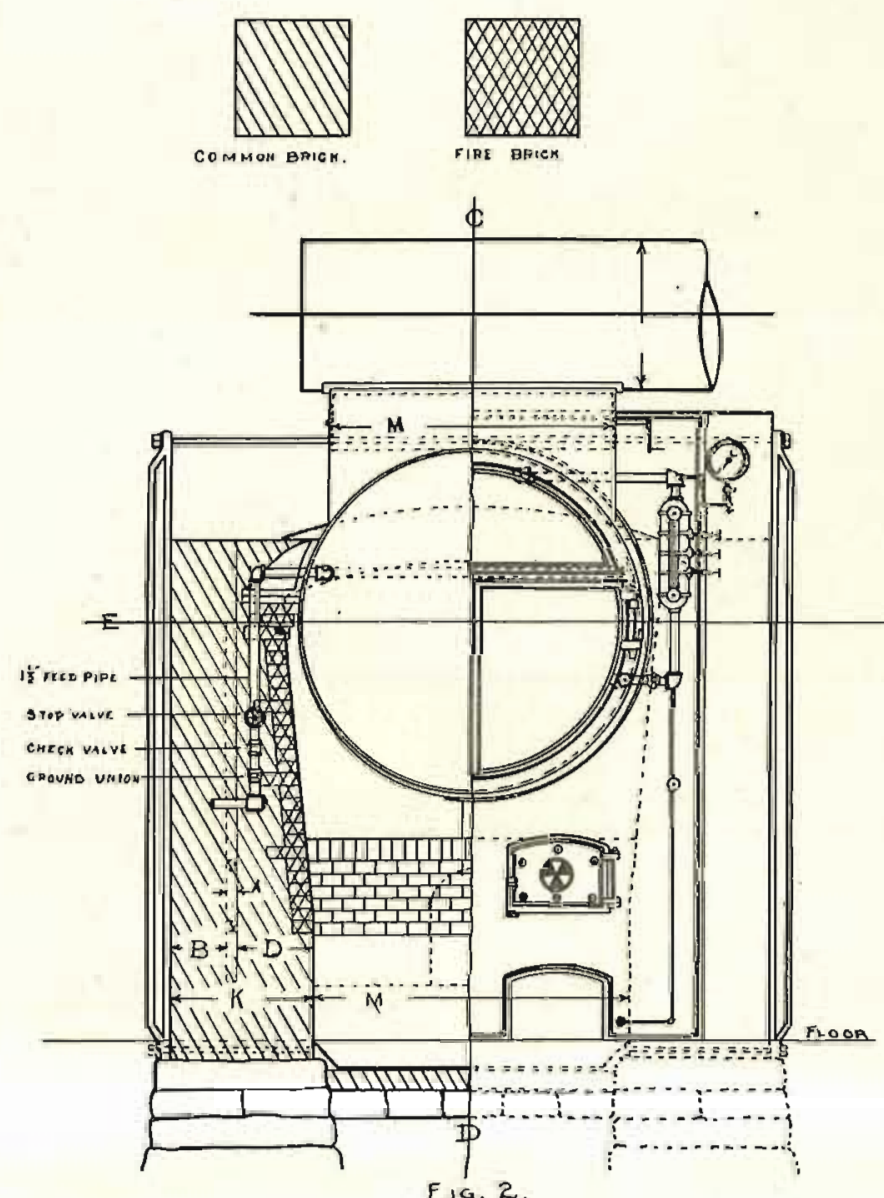

Transvease section of Walhs front Elivation AT "A-B" FIGS, $1: 3$

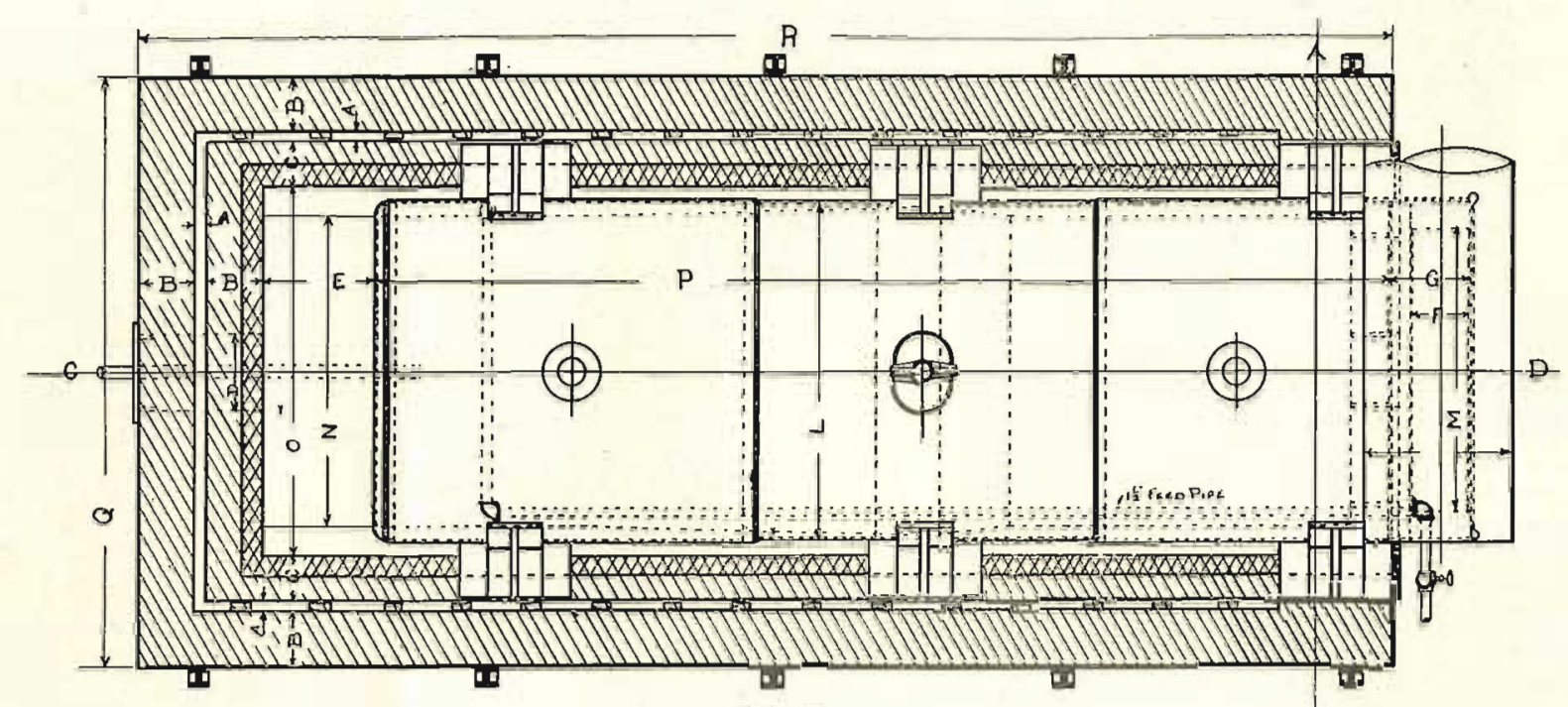

Horizontal SEction of WalzS At E.F. FigS. 2 \& 3.

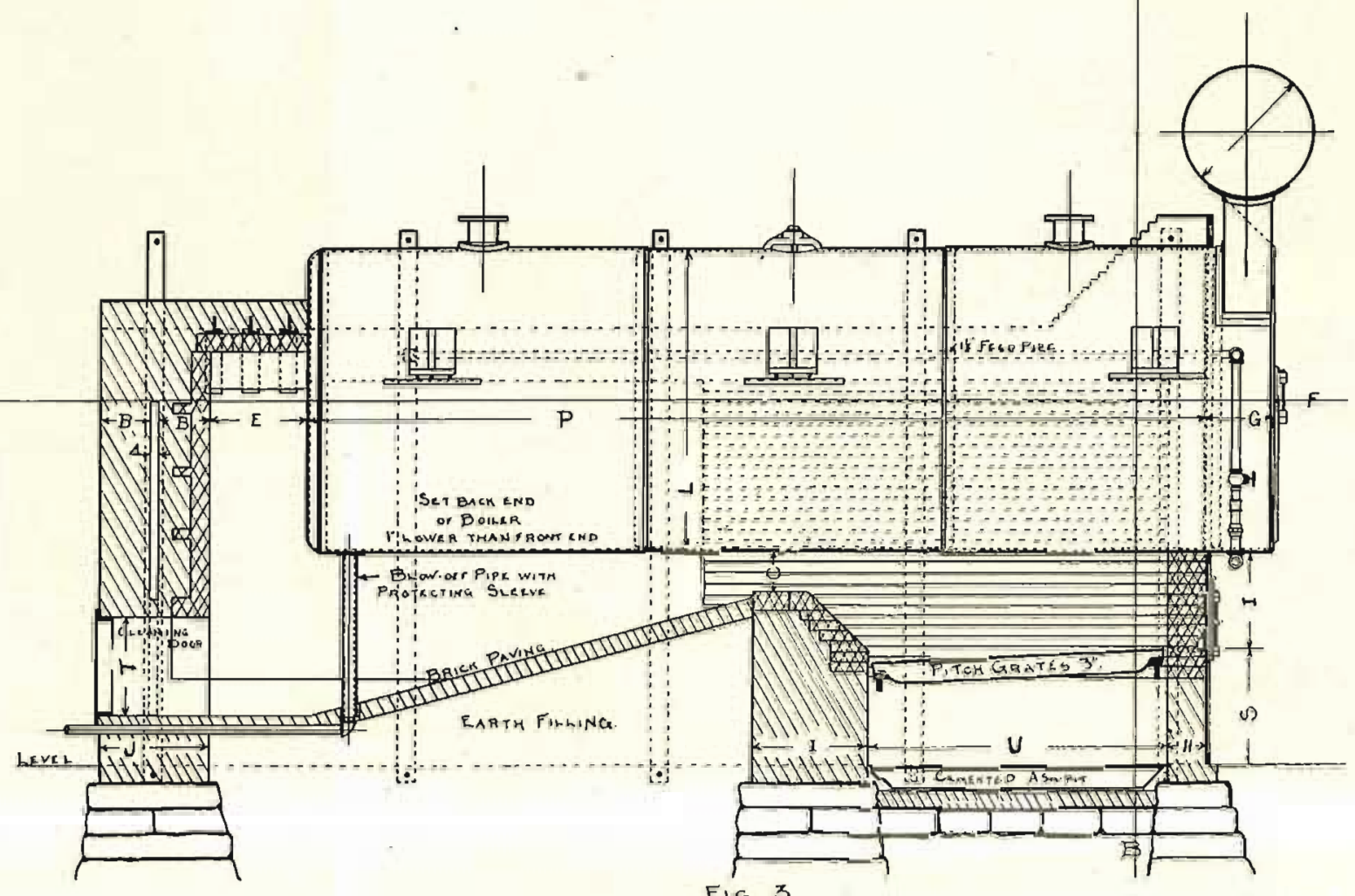

LONGITUDINAL SECTION OF WALLS AT "C.D" FIGS. 1 \& 2. 
A substantial brick stack is better than an unlined stsel stack such as is commonly furnished with boilers, but a self" supporting steel stack lined to the top with brick is considered good and costs somewhat less than an all-brick stack.

For Iowa feed-water the boiler should be made as accessible as possible for interior examination and cleaning. To this end a. man-hole below as well as above the tubes is a necessity.

A dome is not desirable, and its cost can be saved by omitting it from the specifications.

The feed-water should be introduced at the front and above the tubes, below the water line, through a pipe extending to within two feet of the hack head, and discharged downwards between the tubes and the shell.

The boiler should preferably be hung on columns by means of equalizing levers and hangers, so as to keep the sheli free from strains due to settling of the brick work.

A metbod of hanging a shell boiler which ean be applied to a boiler of any size is shown in plate XXVII as designed by the writer for a 54-inch boiler, 16 feet long.

Plate XXVITT shows the stundard setting plans for a 72-inch by 18-loot boiler. For other: sizes the thickness of walls would be the same, but the general dimensions would conform to the size of the boiler shell. The overhanging front shown is better than the flush front. Two lugs on each side would be better than three, as shown.

Size of Boiler.-The boiler must be large enough to drive the engine and the drills. The information needed must be obtained from the builders of the machines and a margin allowed for poor coal or freman or both. It is impossible to state a general rule for determining the size of the boiler except twelve square feet of water heating surface equals one horse-power of boiler capacity for this class of work.

BOILER FEEDING

The most reliable boiler feeder is a direct acting single or duplex pump as illustrated in Figures 2 and 3 anil plate XXJX. The exhaust therefrom can be used to help in the heating of the feed-water as explained later. A second pump, or an injector, should be installed in reserve. 


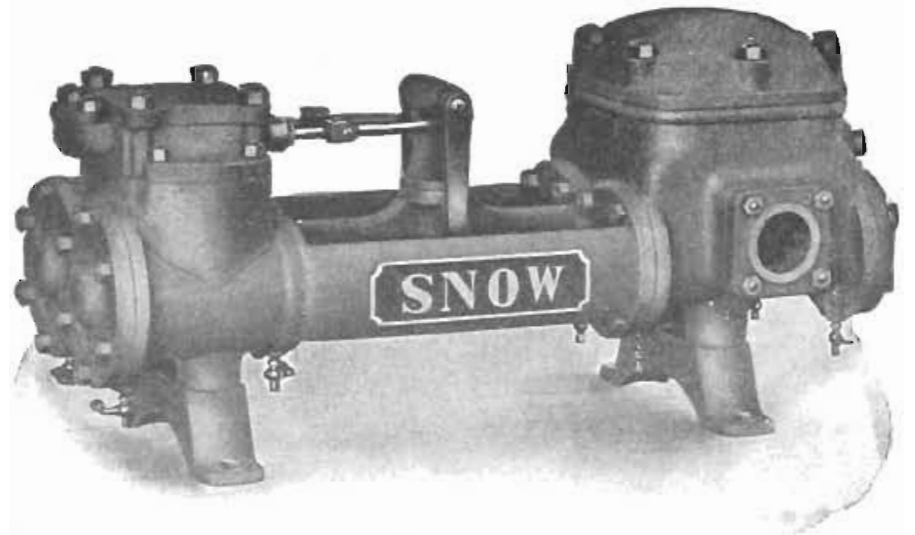

Fig. 2-Type of boiler feed-pump, duplex.

The use of cold feed-water, where it can be heated by otherwise waste heat, is uneconomical. It is perfectly practicable by means of exhaust steam from the auxiliary engines (pumps), or the main engine, to heat the feed-water to 200 degrees $F$., or even 210 degrees $F$. This will effect a saving of 10 per cont or more in the fuel consumed by the boiler.

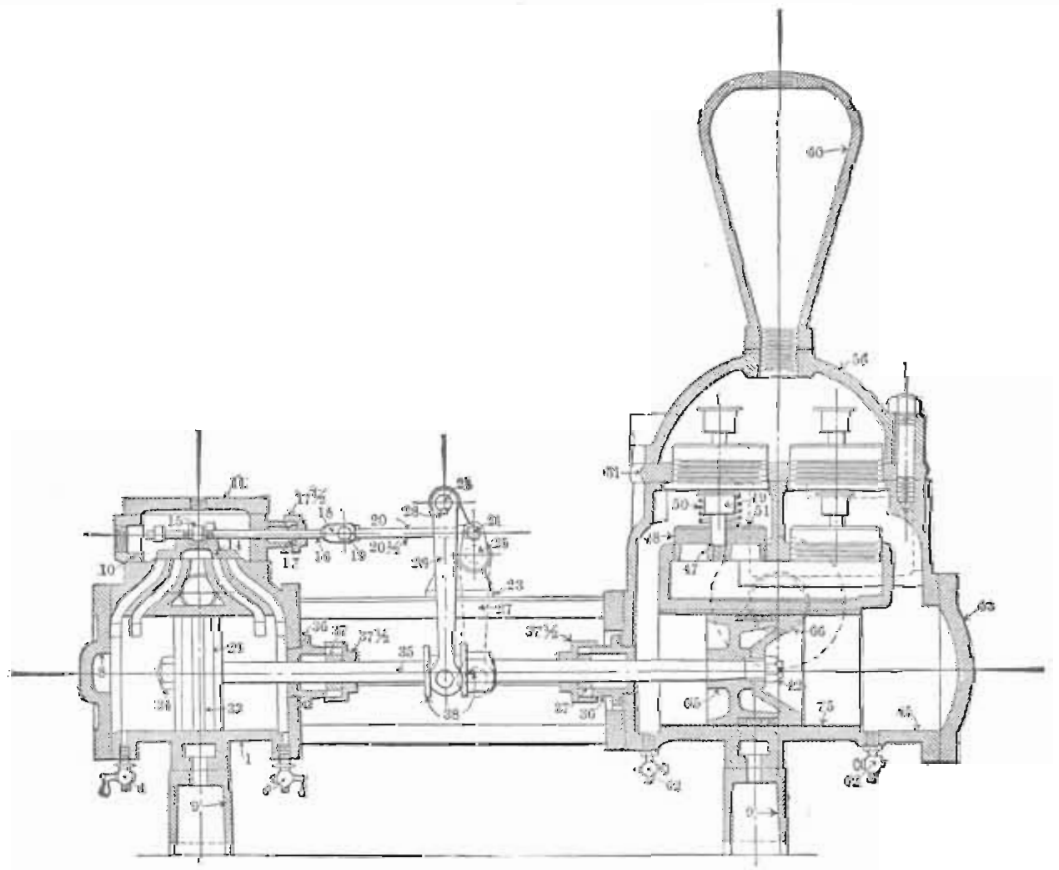

Fig. 3-Duprex purnp in section 


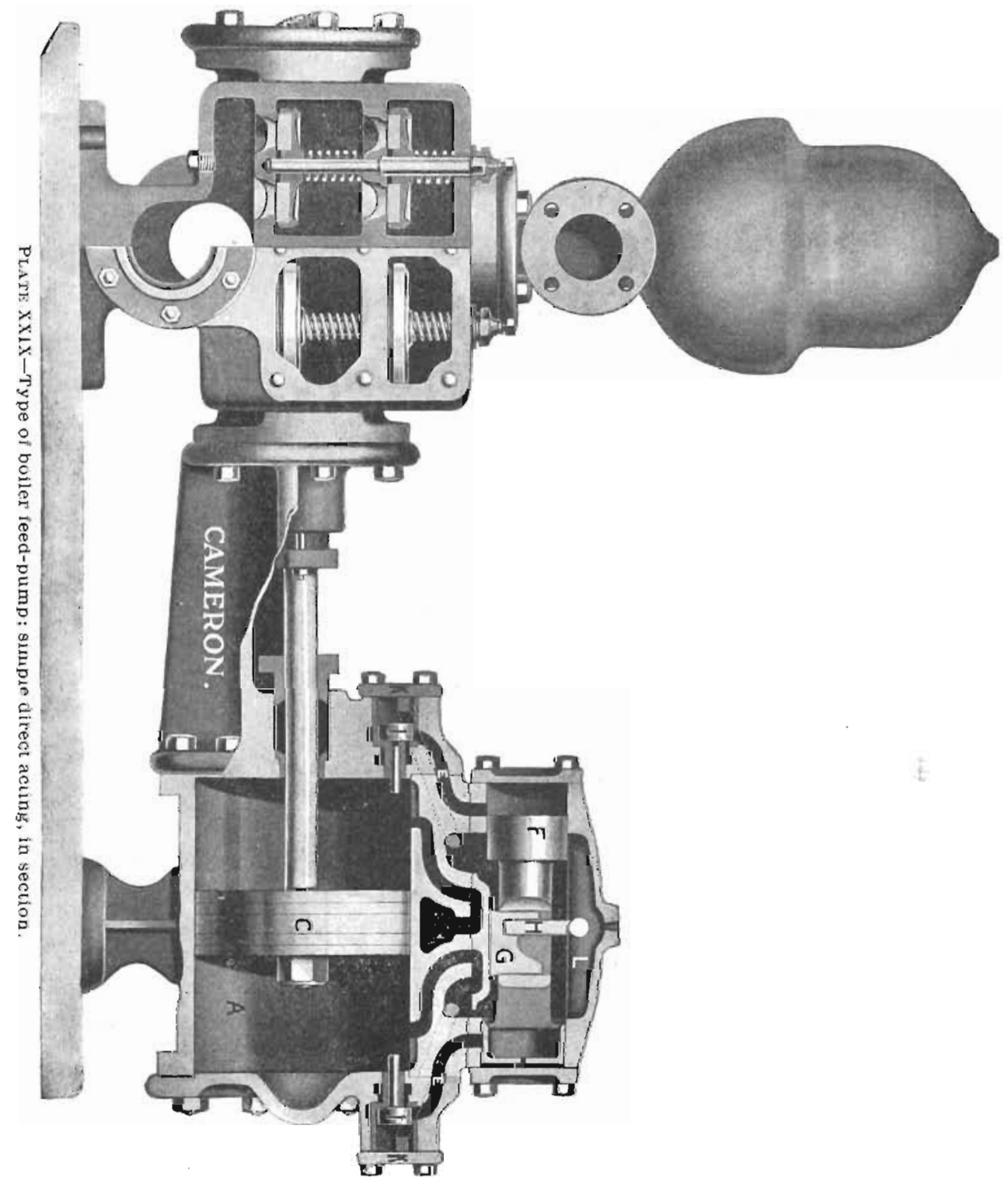


The use of cold feed-water is also bad for the boiler, because of sudden strains thrown upon the shell plates and seams, which lessen the life of the boiler.

Feed-water heaters can be built so that they will act as purifiers, thus counteracting in a measure, the "hardness" of the feed-water.

The cost of a heater and purifier is insignificant compared with the saving effected by its installation and use.

When waste heat is applied to the feed-water the saving which may be effected is given by the following table:

TABLE GIVING PERCENTAGE OF FUEL SAVED BY HFATINi FEED-WATER.

(Steam Pressure, 80 Pounds.)

\begin{tabular}{|c|c|c|c|c|c|c|c|c|c|}
\hline \multirow{2}{*}{$\begin{array}{c}\text { Initial } \\
\text { Temper- } \\
\text { ature of } \\
\text { Water }\end{array}$} & \multicolumn{9}{|c|}{ Temperature of Water Entering Boiler-Degrees F. } \\
\hline & $160^{\circ}$ & $180^{\circ}$ & $200^{\circ}$ & $202^{\circ}$ & $204^{\circ}$ & $206^{\circ}$ & $208^{\circ}$ & $210^{\circ}$ & $212^{\circ}$ \\
\hline $40^{\circ} \mathrm{F}$. & 10.23 & 11.93 & 13.64 & 13.81 & 13.87 & $1+.15$ & 14.32 & 14.49 & 14.66 \\
\hline $50^{\circ} \mathrm{F}$. & 9.46 & 11.18 & 12.90 & 13.07 & 13.24 & 13.41 & 14.58 & 13.75 & 13.92 \\
\hline $60^{\circ} \mathrm{F}$. & 8.67 & 10.40 & 12.13 & 12.31 & 12.48 & 12.65 & 12.83 & 13.00 & 13.17 \\
\hline $70^{\circ} \mathrm{F}$. & 7.87 & 9.62 & 11.37 & 11.54 & 11.72 & 11.84 & 12.06 & 12.24 & 12.41 \\
\hline $80^{\circ} \mathrm{F}$. & 7.08 & 8.85 & 10.61 . & 10.78 & 10.9 .5 & 11.12 & 11.29 & 11.46 & 1.1.6.3 \\
\hline
\end{tabular}

There are many forms of exhaust feed-water heaters on the market. They may be classified as open heaters and closed heaters.

Fig. 4 shows in diagram the essential features of the open heater and Fig. 5 those of the closed heater.

Two principal differences are noted. In the open heater the steam and the feed-water are in contact and the feed-water is not under pressure. In the closed heater the steam and the feed-water are under pressure.

In general there are claimed for the open heater the following principal advantages:

1. The open heater is essentially more efficient than the closed heater, because the steam which furnishes the heat comes into intimate contact with the water to be heated, and the resulting temperature of the latter is higher than can be in the case of the closed heater, wherein all heat transfer must be effected through metal partitions which offer some resistance 
to such transfer. With water free from scale-forming solids and from grease, this resistance is practically negligible where the metal partitions are of elean copper, but in the majority of lases the feed-water is far from pure and the conductivity of the metal partitions is seriously impaired hy scale and grease.

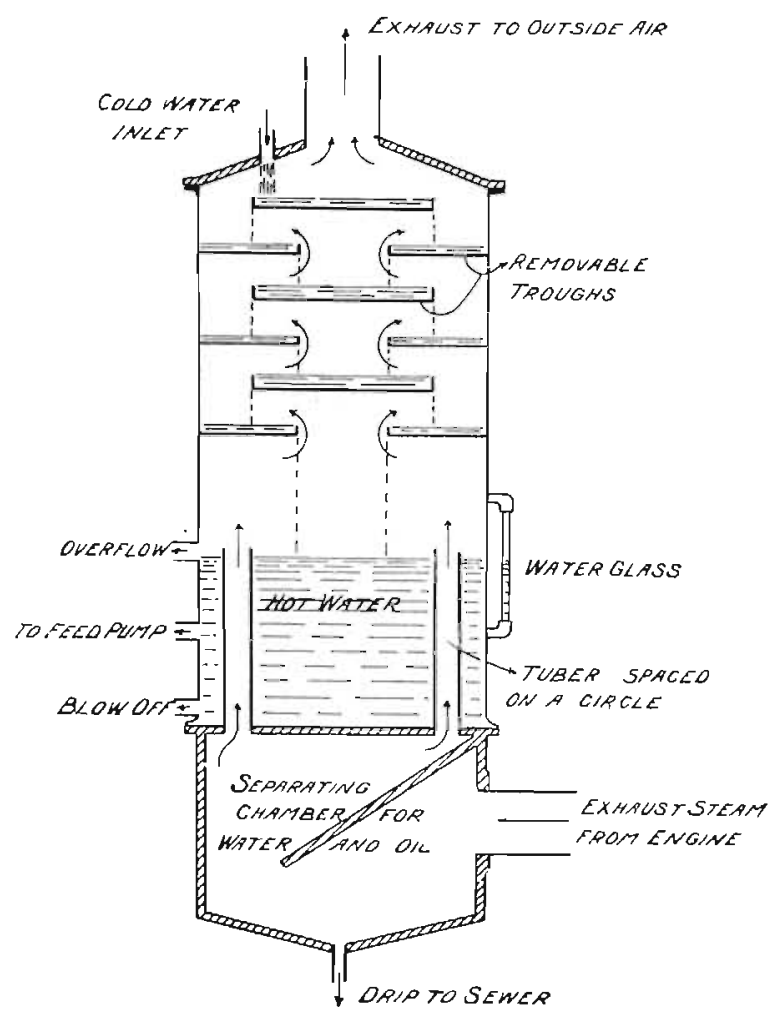

Esg d-open lerd-water henter.

2. The open heater, as usually constructul (se Fig. t), is provided with pans, trays or troughis over which the feed-rater passes at a low velocity, depositing thereon much of the scaleforming matter; in fact, a portion of the scale is deposited in the heater instead of in the boiler. This partial purification is effected withont impairing the elficiency of the heater. In the closed heater the deposition of the sale on the metal partition is objectionable as above staterl. 
3. If, for any reason, the exhaust steam of the main engine is otherwise utilized, the exhaust steam from the feed pump and other auxiliaries can be used in either style of heater. In either case most or all of it will be condensed by the feen-water. In the open heater this results in a direct saving in the amount of water required for the rlant.

4. In the open heater the air in the feed-water is largely liberated by the heat and passon off with the whanst steam. In general the closerl heater shomld he used if the water is very

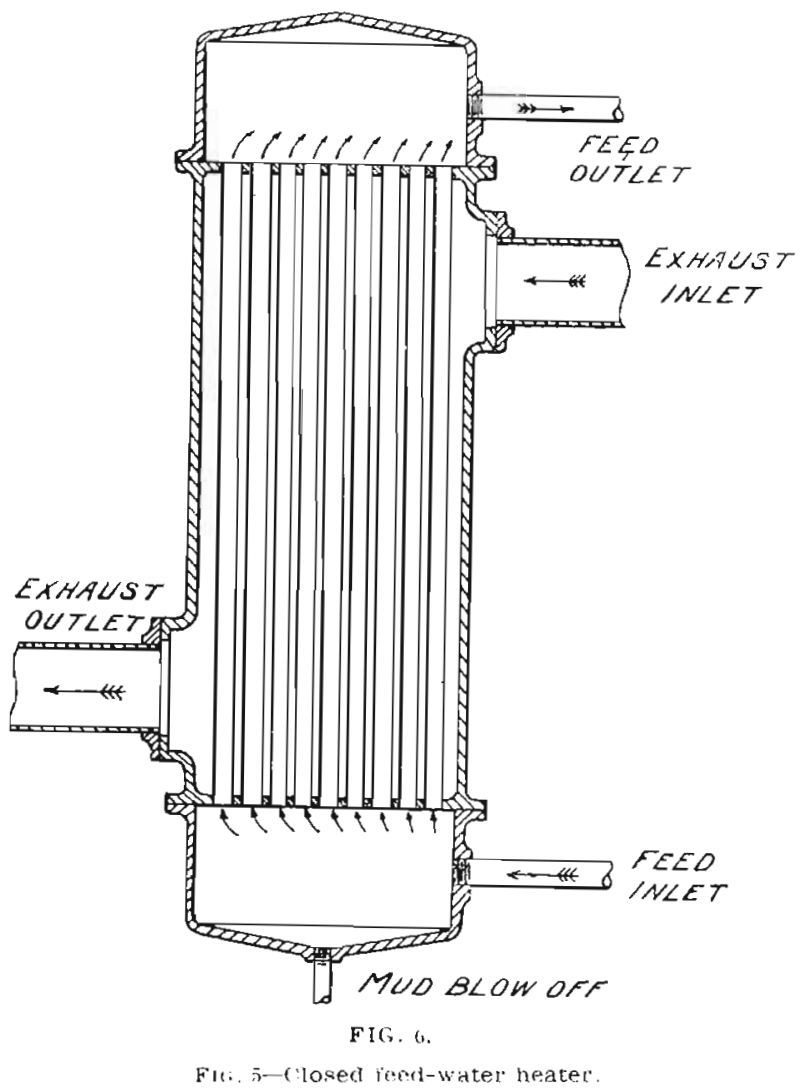

free from mineral impurities or contains only those impurities which will not precipitate at the temperatures attainable with exhaust feed-water heaters.

If the closed heater is used it should be placed in the main exhanst pipe and the feed-watr. mar be handled with an injector 
arranged to deliver to the boiler through the heater, thus saving the difference in cost between a pump and an injector. All things taken into account, the open heater will best meet the needs of the plants under consideration.

In selecting an open heater the following features should be required:

1. A separator, either as an integral part of the heater itself, as indicated in Fig. 4, or as a separate appliance in the main exhaust pipe, or in each of the exhaust pipes of all engines discharging their exhaust through the heater. The former design is preferred.

2. A reservoir or receiver for the heated water, so designed that the water is kept hot until withdrawn by the pump. One way of constructing such a reservoil: is shown in Fig. 4 . The exhaust steam passes through a number of tubes surrounded by the feed-water.

3. The reservoir should be capacious and provided with blow-off, overflow and water glass. The feed pump connection should be a few inches above the blow-off.

4. A large heating and purifying chamber containing pans, trays or troughs so arranged that the cold feed-water shall flow over all of them in order that the exhaust steam shall be compelled to come in contact with the water on every tray.

5 . The trays should be readily removable and of such construction that the arcumulation of scale thereon can be knocked off or picked off without injury to the trays.

It is a good plan to extract the grease from the exhaust steam used for heating the feed-water, because most cylinder oils are injurions to a boiler when allowed to accumulate therein.

$$
\text { PIRING. }
$$

A bad freman is a poor investment, even if he pay for the privilege of firing, and a good fireman is a jewel. In spite of the extensive use of antomatic stokers in large plants, it remains a fact that intelligent hand firing is more economical than machine firing for most plants. The secret of gooul firing is in securing the right amount of air at all points in the fire. The top of the stack is a good indicator of the economy of the fire box, and a window in the roof of the boiler room, with a man 
under it who will look up, are useful adjunsts to any boiler room.

For the proper handling of his fuel the fireman should have knowledge of its properties. For the information of users of Towa coal the following discussion will be found of value: Iowa coals are almost entirely bituminous and non-coking. "In nearly all cases ordinary breakage of coal yields more or less of cubical blocks of varying size" which are much broken up by transportation and weathering. The amount of breakage depends also upon whether the "long wall" or "shooting" method of mining is used. In the former the coal is undermined and broken off by settling of the roof or wedged down, and in the latter the coal is removed by drilling and blasting. The latter process breaks up the coal very thoroughly and is a quicker process, but lessens the value of the product.

An average of 64 analyses by the State Geologist gives the following chemical composition:

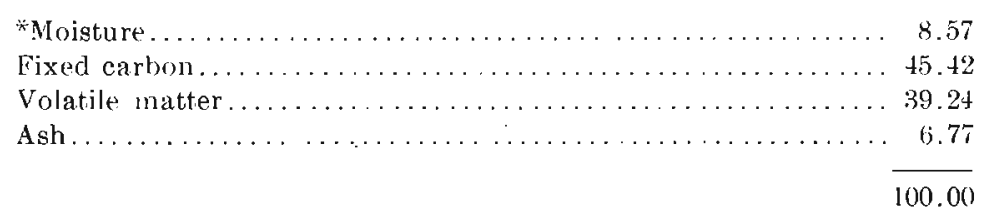

Analyses of coal from 16 mines in the Des Moines River district give :

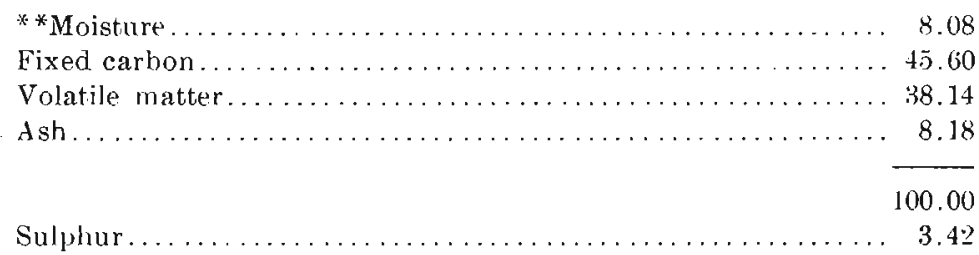

or on the basis of oven dried samples,

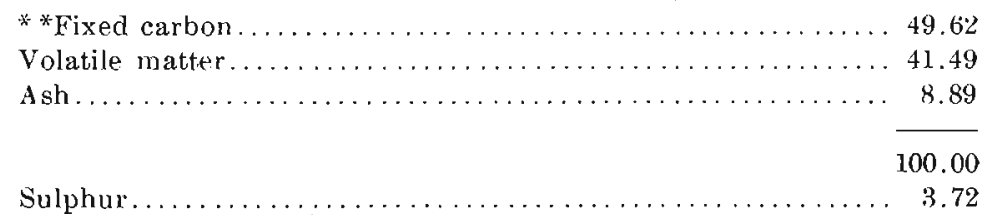

* Steam Boiler Economy, Kent, page 74.

**F.M. Weakly, The lowa Engineer, June, 1902 . 
In 1901-02, at the Iowa State College, Mr. F. M. Weakly made a study of the chemical compositions of Iowa coals, from which the following is quoted:

"The moisture in Towa coals varies (for the coals tested) from 4.03 to 17.47 , the average being 8.08 . This moisture is high, as compared with that in coals of other states.

"Eliminating moisture from our comparisons, in volatile matter the Iowa coals are rich, varying from 36.94 to 48.69 , with an average of 41.49 .

"The fixed carbon ranges from 44.86 to 54.91 , with an average of 49.62 , slightly lower than that of many coals from other states.

"Total combustibles are high, running from 84.88 to 95.91 , with an average of 91.11 .

"Ash is low, being from 4.09 to 15.12 , with an average of 8.89 .

"Sulphur is high, from 2.27 to 7.41 , with an average of 3.72 .

"The coals high in sulphur are also high in ash."

Concurrently with the work of Mr. Weakly, Messrs. Austin and Peshak, under the direction of the writer, determined the calorific powers of samples of coal from twenty or more mines from the same district, fourteen of the samples being the same as used by Mr. Weakly.

The following table exhibits the results of the work of Messrs. Austin and Peshak:

CATORLFLC POWER OF IOWA COALS AND OTHER FUELS.

PER POUND OF DRY FUEI,

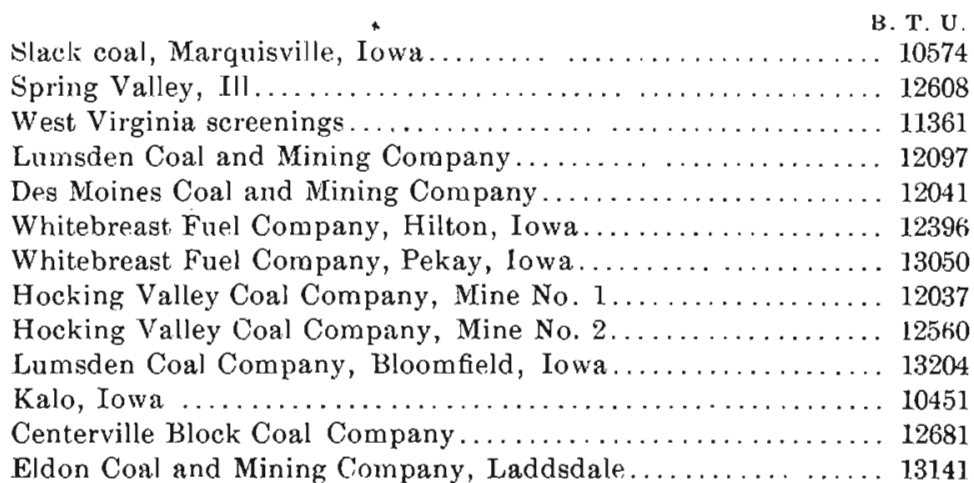


Cousolidated Coal Company, Buxton, No. 10........... 12030

Consolidated Coal Company, Buxton, No. $11 \ldots \ldots \ldots \ldots \ldots \ldots$. 10585

Lodwick Brothers Coal Company, Mystic................ 12780

Carbon Coal Company, Willard...................... 12245

Crcwe Coal Mining Company, Boone................... 12729

Corey Coal Company, Lehigh....................... 12431

Platt Pressed and Fire Brick Company, Van Meter........... 1194]

Jasper County Coal and Mining Company, Colfax... . . . . . . . 12134

Empire Coal Company............................. 10881

A. A. Conway Coal Company...................... 10132

Anthracite coal................................ 12532

Crude petroleum, Beaumont, Texas....................... 19000

Crude petroleum, Chanute, Kansas................... 19:88

ramp black .............................. 44467

\section{CALORIMETER TESTS}

In the subjoined table are presented the heating values and in some cases other information obtained from samples of. Iowa coal gathered from boiler rooms and car lots as delivered to consumers. The Parr Standard Coal Calorimeter was used in the calorimetric determinations.

\begin{tabular}{|c|c|c|c|c|c|c|c|c|}
\hline \multirow{3}{*}{ Designation } & \multirow{3}{*}{ County } & \multirow{3}{*}{ Grade } & \multirow{3}{*}{$\begin{array}{c}\text { B. T. U. } \\
\text { per lo. } \\
\text { Dry Coal }\end{array}$} & \multicolumn{5}{|c|}{ Proximate Analygis } \\
\hline & & & & \multicolumn{2}{|c|}{ Carbon } & \multirow{2}{*}{ Ash } & \multirow{2}{*}{$\begin{array}{l}\text { Moist- } \\
\text { ure }\end{array}$} & \multirow{2}{*}{$\begin{array}{l}\text { Sul- } \\
\text { phur }\end{array}$} \\
\hline & & & & $\begin{array}{l}\text { Vola- } \\
\text { tile }\end{array}$ & Fixed & & & \\
\hline Smoky Hollow & & Stean. & 9719 & 35.4 & 37.8 & 16.0 & 10.8 & \\
\hline Anchor ... & & Stean .. & 9963 & 33.0 & 41.7 & 15.3 & 10.0 & \\
\hline Anchor & & Lump.. & 11027 & 30.7 & 45.0 & 16.0 & 8.2 & 5.03 \\
\hline Roseland. & & steam .. & 8594 & 30.7 & 41.2 & 15,7 & 11.2 & \\
\hline Avery... & & S eam... & 9655 & 34.1 & 39.5 & 15.0 & 11.0 & \\
\hline Colfax. & Jasper.. & Steain .. & $107+2$ & 30.8 & 41.5 & 16.2 & 11.5 & \\
\hline Flint Brick ... & Polk.... & Stean.. & 9952 & 30.1 & 39.5 & 16.2 & 13.0 & \\
\hline Norwoodvilie... & Polk... & Steank. & 10479 & 32.3 & 38.4 & 15.0 & 14.2 & \\
\hline Mammoth Vein. & Marion & Lump. . & 10019 & 33.1 & 37.4 & 15,2 & 14.2 & 4.66 \\
\hline $\begin{array}{l}\text { Gibson Coal } \\
\text { Mining Co }\end{array}$ & Pol & $\mathrm{L}$ & 10244 & 369 & 351 & 140 & 138 & 6.15 \\
\hline Centerville Blk & Appa- & & 10244 & 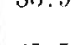 & $\cdots, 1$ & 18.0 & 10.8 & 0.10 \\
\hline & noose. & Lump .. & 10723 & 35.5 & 39.3 & 10.9 & 14.0 & 4.26 \\
\hline Inland Fuel Co. & Lucas .. & Lump.. & 10242 & 30.4 & 41.4 & 12.6 & 15.3 & 3.19 \\
\hline *Johnson, $9 \ldots$ & Boone.. & Slack. & 7363 & 22.1 & 26.1 & 40.1 & 11.7 & \\
\hline Johnson, 5. & Boone... & Lump .. & 11412 & 27.7 & 41.6 & 15.2 & 15.3 & \\
\hline Rogers, $3 \ldots$ & Boone.. & Slack. & 7463 & 20.4 & 26.1 & 41.2 & 12.0 & \\
\hline \& Crowe, 1 & Boone... & Lump. & 9905 & 27.8 & 32.9 & 26.0 & 13.3 & \\
\hline Beaps \& Crowe, 4 & Boone.. & Slack... & 7588 & 14.8 & 31.2 & 42.0 & 12.0 & \\
\hline Marquisville.... & Polk.... & $\mathrm{N}_{\text {ult }} \ldots$ & 11136 & 30.0 & 43.5 & 20.6 & 5.8 & \\
\hline
\end{tabular}

* The number of cars of each kind from which samples were obtained is indicated by the numerals. 
In 1900 boiler tests at the Iowa State College gave the results exhibited in the table below:

TABLE SHOWING COST OF FUEL AND OF STEAM.

\begin{tabular}{|c|c|c|}
\hline Kind of Fuel & 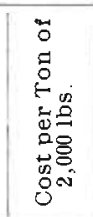 & 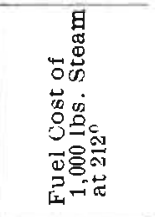 \\
\hline 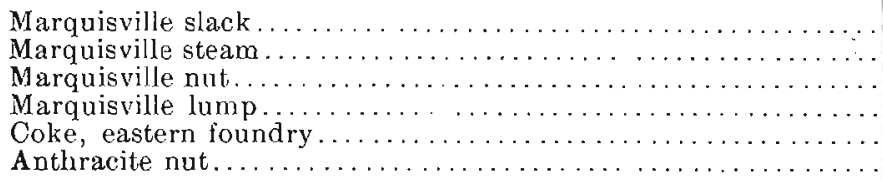 & $\begin{array}{r}\$ 1.43 \\
2.35 \\
2.54 \\
2.28 \\
8.00 \\
8.95\end{array}$ & $\begin{array}{l}14.9 \text { cents } \\
21.2 \text { cents } \\
21.5 \text { cents } \\
24.0 \text { cents } \\
60.4 \text { cents } \\
52.8 \text { cents }\end{array}$ \\
\hline
\end{tabular}

The interesting features of these results are the prolibitive cost of antliracite and coke and the advantage of slack over the better grades of coal from the same mine.

It is evident that transportation charges will materially change the relative values of coal for steam generation. It is also true that the method of handling, the design of the boiler setting and the character of the fuel itself as to ash, sulphur and moisture will materially influence the cost of generating a unit quantity of steam.

Methods of Firing.-Frequent and small charges of fuel intelligently distributed will enable the burning of the poorest fuel with a minimum of smoke and a maximum of economy even in furnaces which are not ideal in their construction. Slack and steam coal should be fired in thin beds, three to six inches, and lump coal ten to twelve inches, and the fires should not be disturbed too often by shaking or poling.

Wetting the fuel before firing is sometimes useful.in promoting coking and preventing the carrying off small particles of unburned coal.

Flues should be frequently cleaned by scraping or blowing with steam or air. A steam jet over the fire is useful when the coal is freshly fired, but is detrimental at other times. If used continuously the loss of heat in the steam is appreciable, and being useless, is inexcusable. 
The ideal conditions for combustion exist when the air supply is from one and one-half to two times the theoretical amount and when the same is thoroughly mixed with the combustible portion of the fuel at a temperature equal to or greater than the temperature of ignition. These conditions can be very nearly attained for Iowa coal if the principles of the boiler and the furnace design and operation above enumerated are followed.

ENGINES.

The selection of an engine is not governed by rules so much as by the individual judgment of the purchaser. Consequently, engines vary more in detail than boilers of the type above discussed.

The writer is of the opinion that up to 100 horse power the moderate speed throttling or automatic engine will best meet the needs of quarrymen. For either type the following general proportions should be observed:

Diameter of steam pipe equal to one-third cylinder diameter.

Diameter of exhaust pipe equal to one-half cylinder diameter.

Diameter of piston rod equal to one-sixth cylinder diameter.

Diameter of shaft equal to one-half cylinder diameter.

Diameter of crank pin equal to one-third to one-half cylinder diameter.

Length of connecting rod equal to three times length of stroke.

The effective power of a single cylinder, high or medium speed engine can be calculated by use of the formula:

Horse power $=0.002 \times \mathrm{L} \times \mathrm{A} \times \mathrm{N}$ wherein

$\mathrm{L}=$ length of stroke in feet.

$A=$ area of piston in square inches.

$\mathrm{N}=$ number of revolutions per minute.

The engines are supposed to use steam at 125 pounds, boiler pressure. Increase in boiler pressure will give a proportionate increase in capacity of engine in either case.

In addition, it should be remembered that durability is proportional to weight, and that weight is cheap in first cost, that convenience in adjustment, simplicity of detail and perfect lubricating devices are essential. 
Engine foundations should be massive and well built. They should rest on hard and natural soil or rock, and the engine should be securely bolted thereto.

Size of Engine.-Double the power required to drive the crusher or other machinery. This margin is necessary to allow for friction and other losses in belts, shafting, etc., and leakage of engine due to wear in service or neglect.

\section{MINOR ITEMS.}

All live steam pipes and fittings and the tops of boilers should be thoroughly lagged with sectional non-conducting covering or its equivalent. Such covering, if of good quality, will last ten or fifteen years and will pay for itself in five years in the saving of heat that would otherwise be lost by radiation. It is important that the pipe covering should be applied with care in order to have the pipe completely covered by the covering, and not merely by the canvass wrapper. The latter should be thoroughly pasted down and the metal bands tightened.

Self-oiling bearings or other continuous oiling devices and an oil filter will save their cost in a year and will last many years.

When properly cared for, the leather belt is the most satisfactory in the long run, but the writer believes that rope transmission will be found to be adapted to quarry work, by the reason of its flexibility and its ability to endure exposure.

Narrow double belts are better than wide single belts of the same weight.

A belt speed of 3,000 feet per minute gives good results. At this speed a double belt, glued joints, one inch wide, will transmit easily four to five horse power if the pull is steady and not jerky.

A rope can be safely run at 4,500 feet per minute, and a oneinch rope at this speed will transmit from a single groove pulley not less than thirteen horse power.

TRANSMISSION OF STEAM TO THE DRILLS.

The steam main should be carried on posts with brackets and can be conveniently protected from rain and excessive condensation by an inverted wooden trough covered at the joints with tar paper or equivalent. 
The pipe should be supported every ten feet and should have if possible, a uniform grade in the direction of flor, of not less than one-half inch to ten fert. When a continuous grade cannot be obtained the low points should be provided with drips. The size of pipe for a given number of drills will.depend upon the steam required to operate them and upon the distance which the steam has to be carried.

In a large plant, it will pay to put up a good steam line and to protect it with efficient eovering, because wet steam will not drive a drill as economically as dry steam. If the steam reaches the drill wet the water should be "dripped" off before entering the drill.

The steam should be shat off from the pipe line when the drills are not needed, as at night or any other considerable period of time.

\section{Gas Engine Power for Quarries.}

At present the gas engine is not sufficiently reliable for the uses of the quarry. The writer believes, however, that the gas engine will some day enter this field in those parts of Iowa where coal is expensive and that the power expense of quarrying will thereby be materially reduced. With it will come the air compressor and air drill or the dynamo and the electric drill, both of which have been successful in mining operations.

In this connection, attention is invited to certain tests made by the United. States Geological Survey during the period of the Louisiana Purchase Exposition and at the government testing plant established there. These tests can be studied in detail by referring to Bulletin No. 261, United States Geological Survey, obtainable through your Congressman, or by direct application to the Survey at Washington. 


\begin{tabular}{|c|c|c|c|c|c|c|c|}
\hline \multirow[b]{2}{*}{ Samples } & \multicolumn{2}{|c|}{ B. T. U per lb. } & \multicolumn{2}{|c|}{$\begin{array}{c}\text { Average } K . W \\
\text { at switch- } \\
\text { board }\end{array}$} & \multicolumn{2}{|c|}{$\begin{array}{l}\text { Dry coal per } \\
\text { K. W. hour }\end{array}$} & \multirow{2}{*}{ 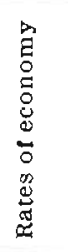 } \\
\hline & 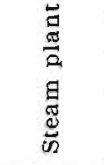 & 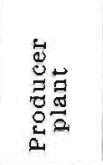 & 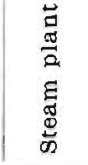 & 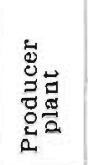 & 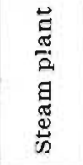 & 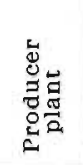 & \\
\hline Alabama No. 2 . & $12,5 \% 5$ & 13,365 & 158 & 148 & 5.50 & 2.21 & 2.48 \\
\hline Colorado No. 1. & 12,077 & $12,2+5$ & 115 & 148 & 6.51 & 2.30 & \\
\hline Illinois No. $3 \ldots$ & 12,857 & $13,0+1$ & $1+7$ & 148 & $5.8 \overline{5}$ & 2.41 & 2.4 \\
\hline Illinois No. $4 \ldots$ & 12,459 & 12,834 & $1+5$ & 148 & 6.47 & 2.37 & \\
\hline Indiana No. 1. & 13,377 & 13,037 & 163 & 148 & 5.56 & 2.60 & \\
\hline Indiana No. $2 \ldots \ldots \ldots$ & 72,$4 ; 2$ & 12,903 & $1+2$ & 149 & 5.85 & 2.08 & $\because .81$ \\
\hline Indian Territory No. 1 & $1:, 8: 34$ & $13,4 \overline{3} 5$ & 143 & 152 & 5.44 & 2.46 & 2.21 \\
\hline Kentucky No. $3 . . . .$. & $13,03 \mathrm{i}$ & $13,2 \div 6$ & 155 & 148 & 5.68 & 2.57 & 2.21 \\
\hline Missouri No. $2 \ldots \ldots$ & 11,500 & $11,88: 2$ & 152 & 128 & 6.62 & 2.30 & \\
\hline West Virginia No. 1 . & 14,198 & 14,396 & 146 & 148 & 5.25 & 2.12 & 2 \\
\hline West Virginia No. 4. & $1+, 002$ & 14,202 & 157 & 148 & 4.87 & 1.74 & 2.8 \\
\hline West Virginia No. 9 & 14,616 & 14,580 & 1.54 & 149 & 4.66 & 2.14 & 2.7 \\
\hline West Virginia No. 12. & 15,170 & $14,8 \div 5$ & 151 & 148 & 4.75 & 2.02 & 2.35 \\
\hline Wyoming No. $2 \ldots$. & 10,897 & 10,656 & 135 & 149 & 7.94 & 2.78 & 2.85 \\
\hline Averages. & 13,037 & $13,10^{\circ}$ & & & 5.71 & 2.29 & 2.49 \\
\hline
\end{tabular}

In the above tab]e are shown the principal results of steam and producer gas engine tests of certain soft coals, some of which are comparable with Iowa coals. Fourteen tests are here quoted. The favorable showing of the producer gas engine in these tests is significant. While it is true that the steam engine used was a simple non-condensing engine having a "water-rate" of 23.6 pounds, it is also true that the gas engine in the large sizes is still in an experimental stage, especially in those features of its design and operation which affect its utility in plants where only ordinary skill can be expected to be exercised.

Of the coals listed in the above table, Missouri No. 2 resembles most closely the Iowa coals -its principal proportions being

Moisture..................................... 11.60

Carbon, volatile............................ 35.28

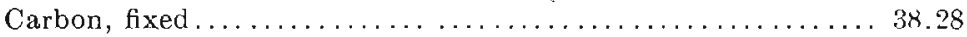

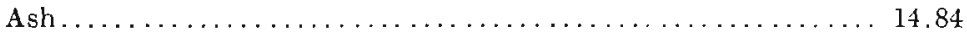

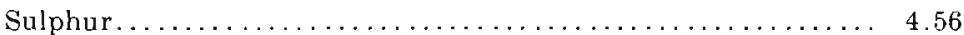

Calorific value.......................... 11500 to 11882 
and the average of Iowa coals being

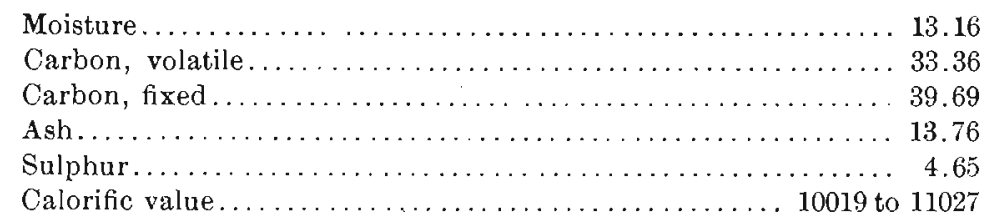

"The high percentage of sulphur in the coal did not add to its value as a producer fuel," is a remark made in the government report in connection with these tests, which sentiment has been modified materially in the view of later experience to which reference is had below.

The lack of correspondence between the relative values of the several coals in the table for steam and producer tests indicates that a given producer may be better adapted for handling a wide variety of coals than is a given boiler furnace.

The table also shows that for these tests and conditions the percentage saving in fuel of the producer over the steam plant is greater for the poorer coals, and this is an entirely reasonable view because the volatile constituents of the coal in the producer escape only through the engine cylinder in which their combustion is quite completely effected; whereas, with steam generation with volatile fuels under a boiler, various and large proportions of the volatile matter escape to the chimney unburned.

The tests above quoted were largely in the nature of preliminary tests and considerable difficulties were met with in obtaining reliable results.

In the year following the exposition, viz., 1905, better arrangements were available for the tests, and the matter was again entered into much more thoroughly. A notable change in the conditions surrounding the second series of tests was in their length. It was possible to secure continuous periods of operation for each test of from forty to sixty hours, which was not possible in the earlier tests. 


\begin{tabular}{|c|c|c|c|c|c|c|}
\hline \multirow{2}{*}{ Samples } & \multirow{2}{*}{$\begin{array}{l}\text { B. T. U. } \\
\text { Per ib. } \\
\text { Dry coal }\end{array}$} & \multirow{2}{*}{ Ash } & \multirow{2}{*}{ Sulphur } & \multicolumn{2}{|c|}{$\begin{array}{c}\text { Dry Coal Per K. } \\
\text { w. Hour. }\end{array}$} & \multirow{2}{*}{ Ratio } \\
\hline & & & & Steam & $\begin{array}{c}\text { Pro- } \\
\text { ducer }\end{array}$ & \\
\hline 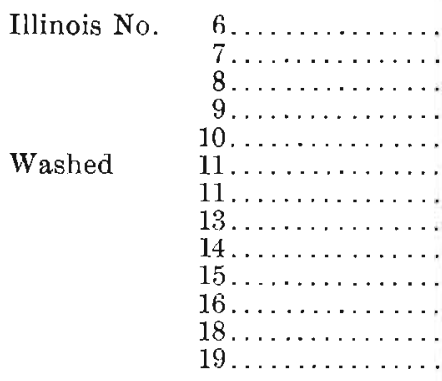 & $\begin{array}{l}12762 \\
12730 \\
12020 \\
12438 \\
12929 \\
12348 \\
13370 \\
12600 \\
12060 \\
11749 \\
12874 \\
12970 \\
13000\end{array}$ & $\begin{array}{r}16.0 \\
18.9 \\
11.6 \\
11.5 \\
10.6 \\
10.8 \\
11.5 \\
10.2 \\
12.4 \\
13.5 \\
10.3 \\
10.0 \\
9.4\end{array}$ & $\begin{array}{l}4.6 \\
4.15 \\
4.64 \\
4.92 \\
1.35 \\
2.09 \\
1.65 \\
1.66 \\
4.16 \\
4.06 \\
1.47 \\
4.59 \\
0.53\end{array}$ & $\begin{array}{l}7.13 \\
5.85 \\
7.41 \\
7.00 \\
7.70 \\
6.02 \\
6.62 \\
6.12 \\
7.16 \\
6.82 \\
5.70 \\
6.40 \\
5.65\end{array}$ & $\begin{array}{l}2.40 \\
3.50 \\
2.31 \\
2.38 \\
1.95 \\
1.82 \\
4.00 \\
2.14 \\
2.10 \\
2.18 \\
2.25 \\
2.03 \\
1.79\end{array}$ & $\begin{array}{l}2.98 \\
1.67 \\
3.20 \\
2.94 \\
3.95 \\
3.32 \\
1.65 \\
2.87 \\
3.40 \\
3.14 \\
2.54 \\
3.15 \\
3.16\end{array}$ \\
\hline \multicolumn{6}{|l|}{ Average.. } & 2.92 \\
\hline 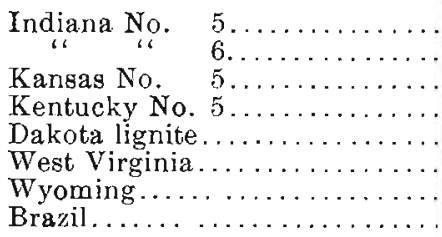 & $\begin{array}{c}12600 \\
12505 \\
\cdots \ldots \ldots \\
14500 \\
14500 \\
10518 \\
9900\end{array}$ & $\begin{array}{r}11.5 \\
12.5 \\
10.2 \\
4.0 \\
11.4 \\
3.5 \\
15.3 \\
23.4\end{array}$ & $\begin{array}{l}5.00 \\
4.71 \\
3.18 \\
0.47 \\
3.54 \\
0.82 \\
7.36 \\
2.94\end{array}$ & $\begin{array}{c}6.41 \\
6.41 \\
\cdots \cdots \\
4.83 \\
\cdots \cdots \\
4.64 \\
7.96 \\
8.85\end{array}$ & $\begin{array}{l}2.20 \\
2.32 \\
2.02 \\
1.79 \\
2.55 \\
1.36 \\
2.40 \\
3.12\end{array}$ & $\begin{array}{r}2.92 \\
2.77 \\
\cdots \\
2.69 \\
\cdots \\
3.41 \\
3.31 \\
2.84\end{array}$ \\
\hline
\end{tabular}

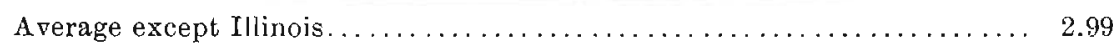

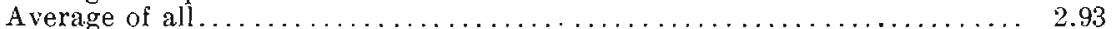

The preceding table gives a comparative summary of a number of soft coals itested in 1905 , both on the steam plant and the producer plant. The results are very interesting and confirm in a general way the advantages of the producer plant indicated by the earlier tests. In the earlier tests, as shown in the first table, the ratio of economy of the producer to the steam plant was 2.49. In the tests of 1905 , the average ratio for the Illinois coals was 2.92 , and for sundry other coals used, 2.99 , and for the nineteen coals as shown in the second table, the average was 2.93 .

The following summary of the 1905 tests is taken from Bulletin No. 290, United States Geological Survey.

"The results of the majority of the tests have been exceedingly gratifying, official records having been made as low as 0.95 pound of dry coal per hour burned in the producer per 
electrical horsepower developed at the switchboard, or 0.80 pound of dry coal per hour burned in the producer per brake horseporrer, on the basis of an assumed efficiency of 85 per cent for generator and belt.

"Throughout the tests a constant effort has been made to do away with unneressary appliances. This effort has furnished valuable and interesting information and has centered attention on several radical changes in the details of prodncer gas plant construction.

"It was found at an early date that more or less sulphur was passing the purifier and entering the engine cylinders. Investigations by the chemists showed that purifiers consisting of oxidized iron filings and slavings are fairly effient for coals containing little sulphur-1 per cent or less; but it was found that for coals containing larger percentages of sulphur the purifier became completely exhausted after about six or eight hours. Mixtures of lime and shavings were tried, but with little success. As a result of these investigations, the purifies: has beeu discarded, and the gas, carrying its full percentage of sulphur, has been charged directly into the engine cylinders. This method of operating has been going on for many months, and no ill effects have been riscovered, though coal has been used containing as high us 8.1 per cent of sulphur.

"One feature of the plant as installed was the economizer, used for preheating the air for the blast. A series of experiments has shown no effect on the chemical composition of the gas or on the efficiency of the plant when air at ordinary atmospheric temperature was substituted for preheated air. As a result the economizer, as an economizer, las been discarded, and the construction of the plant again simplified.

"Other modifications and changes, are under investigation at the present time, the must important, 1 'rom an economic standpoint, relating to the utilization of slack coal in producers."

In addition to the above the writer presents the principal results of a test of a hard coal producer gas engine made under hi.s direction, in the spring of 1906 . The engine was a three-cylinder, vertical, Fairbanks Morse engine, using gas generated from anthracite pea coal in a suction gas producer, also manufactured by the Fairbanks Morse Co. The unit is rated at 150 brake horse- 
power at 250 revolutions per minute, and was guaranteed to give one brake horsepower hour for not to exceed one and one-half pounds of anthracite pea coal for all loads above seventy-five brake horsepower.

\begin{tabular}{c|c|c|c}
\hline \hline $\begin{array}{c}\text { Revolutions } \\
\text { minute }\end{array}$ & $\begin{array}{c}\text { Brake load, horse- } \\
\text { power }\end{array}$ & $\begin{array}{c}\text { Pounds coal (as ared) } \\
\text { per brake horsepower } \\
\text { per hour }\end{array}$ & $\begin{array}{c}\text { Cost per brake horse- } \\
\text { power hour at } \$ 6.00 \\
\text { per ton }\end{array}$ \\
\hline & & 1.511 & $\$ 0.00453$ \\
250 & 40.1 & 1.157 & .00347 \\
250 & 156.7 & 0.999 & .00299 \\
\hline
\end{tabular}

Two tests were also made on this engine under service conditions, viz. : belted to a $75 \mathrm{~K}$. W. alternating current generator. In addition to the lighting load, electrically driven pumping machinery can be operated from this generator.

Fig. 6 shows the load curve (A) during a service run with lighting load only and the load curve (B) for the combined load, the usual operating conditions, stand-by losses included.

At $\$ 6.00$ per ton the cost of fuel per K. W. hour at the switchboard for the load A was $\$ .01207$ including fuel for banking and starting, and for the load B was \$.00639 including also the standby losses.

Soft coal from Illinois which was used for a Corliss engine unit in the same plant cost $\$ 3.40$ per ton.

For the purpose of comparison with this test, we may consider the case of a simple Corliss engine similar to that used in the government tests at St. Louis. The average coal consumption of that engine, according to table on page 177, was 5.71 pounds per K. W. hour. If this coal cost $\$ 3.00$ per ton the cost of the coal per K. W. hour would be $\$ 0.0085$, which ean be eompared directly with the values given in connection with the Algona test.

It is difficult at this time to predict the immediate future of the producer gas engine, but the writer believes that this type of prime mover is destined to be a formidable rival of the steam engine, and as the price of fuel increases the field for the producer gas engine will enlarge. At present there is a question whether it will pay to install a producer gas engine where coal is cheap. The only advantage would be the compliance.with the 
smoke regulation, but as a financial proposition it may be stated that owing to the fact that a producer gas engine installation costs probably from 50 per cent to 60 per cent more than a steam engine plant which would be its alternate, it will not pay to consider the installation of the gas producer plant with coal costing $\$ 1.25$ or less per ton.

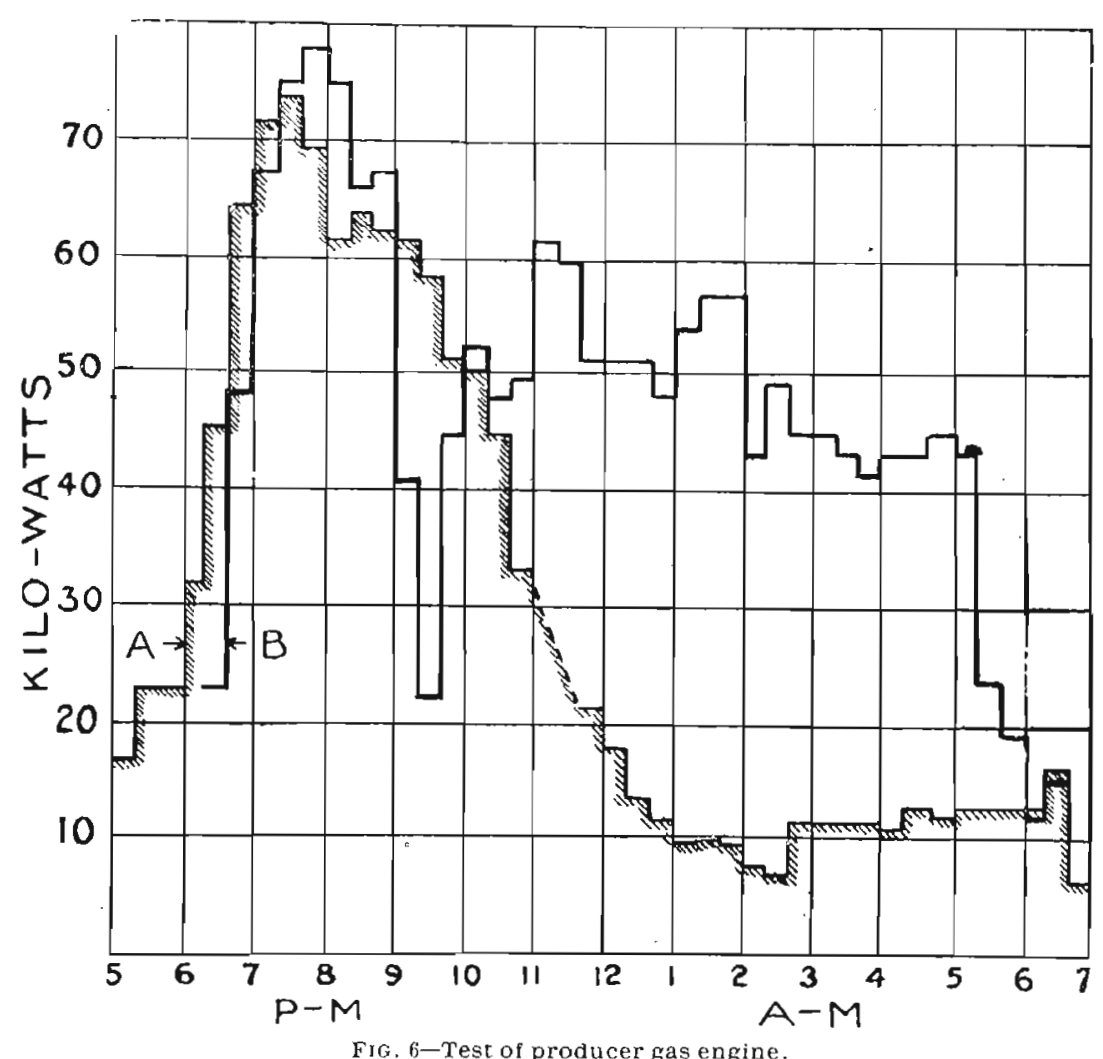

A.-Load curve of Algona producer gas engine, Mar. 15-16, '06.

Fourteen hour test. Output $409 \mathrm{~K}$. W. hours.

Anthracite pea coal per K. W. H. $=4.10$ los.

Fuel cost per K. W. H. $=\$ 0.0123$.

Load factor 18 per cent.

B. - Load curve of A Igona producer gas engine, Mar. 16-17, '06.

Twelve hour test. Output $589 \mathrm{~K}$. W. hours.

Anthracite pea coal per $\mathrm{K} . W . H .=2.23 \mathrm{lbs}$

Fuel cost per K. W. H. $=\$ 0.00699$.

Load factor 27 per cent. 
The question of the mechanical and operative advantages and disadvantages of the gas engine will not be discussed here except to say that there is no reason why the gas engine can not be used satisfactorily for the generation of electrical current for light, pumping and power. 


\section{'}

